\title{
One Plot, Different Titles and Tales of Confusion in Nollywood Films: The Example of Bobemmanuel Anosike's Twins but not Brothers, Twins in Sorrow, and Battle of the Twins
}

\author{
Barclays Foubiri AYAKOROMA* \\ Associate Professor, Department of Theatre \& Cultural Studies, Nasarawa State University, Keffi, Nigeria \\ *Corresponding Author: Barclays Foubiri AYAKOROMA, Associate Professor, Department of Theatre \\ \& Cultural Studies, Nasarawa State University, Keffi, Nigeria
}

\begin{abstract}
Nollywood has gone through various phases in its generic development, which have influenced certain production practices. The argument is that most of the prevalent production conventions have been occasioned by the circumstances that surrounded the advent of the industry, which is privately-driven and has serious mercantilist underpinnings. One of such approaches is that three or four films, with the same plot, are packaged, not as parts but as stand-alone films with different titles. This practice has created situations where, rather than help the audience to grow with the industry, viewers are exposed daily to stories that confuse them. The fact is that every well-made film has a storyline with the beginning, the middle, and the end. Extensions of storylines to subsequent parts are made clear to viewers, as the scenes would have been set for such. In this study, three films, namely, Twins but not Brothers (Anosike, 2014), Twins in Sorrow (Anosike, 2014), and Battle of the Twins (Anosike, 2014), have been selected for critical analysis to substantiate the position that, the production of films, not as sequels and not indicating such, ends up confusing viewers. It is a practice reflective of the unscrupulous 'trader mentality' of the executive producers in Nollywood, which needs to be checked by the regulatory bodies. The submission is that even if films are to be packaged as sequels, production conventions need to be followed to enhance the content of such films.
\end{abstract}

Keywords: Plot, Different Titles, Tales of Confusion, Nollywood Films

\section{INTRODUCTION}

The contemporary Nigerian film industry, Nollywood, has undergone various generic developments that have influenced certain production practices. Somehow, most of the prevalent production conventions have been occasioned by the circumstances that surrounded the advent of the industry. The industry is privately-driven and it is not surprising that there are serious mercantilist underpinnings or tendencies. One approach is such that three or four films with the same plot are packaged, not as parts, but as stand-alone films with different titles. The practice has created situations where, rather than help the audience to grow with the industry, they are exposed daily to stories that confuse them. This study has been informed by a reading of three films, Twins but not Brothers (Anosike, 2014), Twins in Sorrow (Anosike, 2014), and Battle of the Twins (Anosike, 2014). It will adopt the filmic narrative technique in the reading of the films. Unfortunately, the preview of the films was in the reverse order, in the sense that, the films were produced, not as sequels and there are no indications as such; thus, one ended up being confused as to the sequence of the films. It is a practice reflective of the unscrupulous 'trader mentality' of the executive producers in Nollywood, which needs to be checked by the regulatory bodies. Thus, the study submits that even if films are to be packaged as sequels, production conventions need to be followed to enhance the content of such films.

\section{On Plot DeVelopment in SCREen Writing}

In his treatise, Poetics, written as far back as 335 B.C., the Greek philosopher, Aristotle, identified what have come to be known as, the six elements of drama. He posited that, every tragedy must have six parts, "which parts determine its quality, namely, Plot, Character, Diction, Thought, Spectacle, Song. Two of the parts constitute the medium of imitation, one the manner, and three the objects of imitation" (Dukore, 1989, p. 36) (Italics mine). In his discourse, Aristotle had emphasised the importance of plot thus: 
Again, if you string together a set of speeches expressive of character, and well finished in point of diction and thought, you will not produce the essential tragic effect nearly so well as with a play which, however deficient in these respects, yet has a plot and artistically constructed incidents (Dukore, 1989, p. 37).

Among other definitions, the New Webster's Dictionary (1995, p. 772) states that, a plot is "the plan of events in a novel, play, etc." In actual sense, a plot is the storyline in novels, plays, films, and so on. It is made up of narrative events that make up a story, as they relate to one another in patterns or sequences. In other words, a plot is the sequential development of events, the cause-and-effect relationship in a story. In practice, plot and plot structure in the treatment are combined by screenwriters. The treatment contains the plot and provides the fundamentals for the screenplay. This structure, according to Harmon (1988: 37), is such that the length of a film is divided into three parts, serving the functions of set-up, confrontation, and resolution, respectively.

Aristotle's Poetics considered plot (mythos) as the most important element of drama, which must have a beginning, a middle and an end. In the analysis of Aristotle, the events of the plot must causally relate to one another as being either necessary or probable. He states thus:

Tragedy is an imitation of an action that is complete, and whole, and of a certain magnitude; for there may be a whole that is wanting in magnitude. A whole is that which has a beginning, a middle, and an end. A beginning is that which does not itself follow anything by casual necessity, or as a rule, but has nothing following it. A middle is that which follows something as some other thing follows it. A well-constructed plot, therefore, must neither begin nor end at haphazard, but conform to these principles (in Dukore, 1989, pp. 37-38).

To Aristotle, of utmost importance is the plot's ability to arouse emotion in the psyche of the audience. This explains why he avers that, in tragedy, the appropriate emotions are fear and pity. He goes on to consider whether the tragic character suffers (pathos), and whether or not the tragic character commits the error with knowledge of what he is doing, illustrating this with the instance of a tragic character, who is about to kill someone in his family. According to him, the worst situation is when with full knowledge, on the point of doing the deed the character leaves it undone. Then there is the actual perpetration of the deed meditated. However, a better situation than that is for the deed that is done in ignorance, and the relationship is discovered afterwards, and the discovery serves to astound the audience.

On the other hand, Rabiger (2003, p. 138) notes that in film techniques and aesthetics, plot is an issue that is complex and closely allied to the structure of a film. He states that, "the plot of a drama is the logic and energy driving the story forward; and its job is to keep the audiences' interest high". This is very true because once an audience loses track of the plot, the message will not be communicated very well. He adds that,

A screenplay's plot only becomes fully visible when you make an outline. Every step the characters take must be logical and inevitable, for anything that is unsupported, arbitrary, or coincidental will weaken the chain of logic that keeps them in seemingly inevitable movement (Rabiger, 2003, p. 138).

As a point of fact, Gustav Freytag had considered plot to be a narrative structure that divides a story into five parts, namely, exposition, rising action, climax, falling action, and denouement (or resolution). These have come to form what is popularly called, the Freytag's Pyramid in playwriting, dramatic literature, and dramatic theory and criticism. It is necessary for us to relate the foregoing to the art of screenplay writing.

\section{ESSENTIALS OF SCREENPLAY WRITING}

Aesthetically speaking, films deal with sight, sound and motion. This is in the sense that the film audiences see people (images) talking and moving, just as every action is heightened with the requisite sound. Elsewhere, we have posited that, "the script is the departure point for every production" (Ayakoroma, 2013, p. 63). Furthermore, Harmon (1988, p. 37) avers that, "a film script is a story told in pictures". However, in line with the position of Aristotle, Harmon notes that, every well-made film has a storyline with a beginning, a middle, and an end. The implication here is that, to be artistically effective, any extension of a storyline to subsequent parts has to be made clear to viewers, as the scene would have been set for such. 
The foregoing amplifies the fact that, a good script is a sine qua non in the art of filmmaking. Thus, it is pertinent to briefly examine the essentials of each of the three segments of the screenplay - the beginning, the middle, and the end - as encapsulated in Freytag's narrative structure, which divides a story into five parts: the exposition (of the situation); the rising action (through conflict); the climax (or the turning point); the falling action; and the denouement. This is in order for us to properly situate the prevailing screenplay writing convention in Nollywood that has mercantilist orientations.

a) The Beginning: This is the story premise; which introduces the main characters of the story, showing how they relate to one another, their goals and counter-goals and motivations, and their moral character. Here, we have the rising action, which starts with a conflict, such as, the death of a character, disagreement over inheritance, struggle over land ownership, struggle over the hand of a girl in marriage, etc. In this phase, the protagonist understands his/her goal and begins to work toward it. Smaller problems thwart the initial success and the progress is directed primarily against the secondary obstacles. This phase demonstrates how the protagonist overcomes the obstacles. Thus, the disagreement in this phase leads to the climax.

b) The Middle: Basically, this is made up of the conflicts and obstacles, which build-up until the climax. It is that point in the plot where all the major characters have been introduced, their motives and allegiances have been made clear, and they have begun to scheme against one another. The conflicts in this phase are: man against man; man against nature; man against himself. The climax, which is the middle of the plot, is the turning or highest point of the story. Here, the protagonist makes the single big decision that defines not only the outcome of the story, but also who he is as a person. To be specific, at the beginning of this phase, the protagonist finally clears away the preliminary barriers and engages with the adversary. As a matter of fact, in this phase, both the protagonist and the antagonist have plans to win against the other. For the first time, the audience sees the pair going against one another in direct or nearly direct conflict; and the struggle results in any of the characters completely winning or losing. In most cases, each character's plan is both partially successful and partially foiled by the adversary. Thus, the main struggle between the two characters is unique in the sense that the protagonist takes a decision which shows his/her moral quality, and ultimately decides his/her fate. In a tragedy, the protagonist here takes a "bad" decision or miscalculates, which demonstrates his/her tragic flaw.

c) The End: This is the denouement, where certain questions are asked, and for which answers are provided. For instance, such questions could be: Is the resolution logical? Is the resolution believable? Is the resolution clearly stated? Has the resolution left any question unanswered? This phase has the falling action, which consists of events that lead, in most cases, to a happy ending. In his phase, the character's actions resolve the problem. In the beginning of this phase, the villain has the upper hand; it could look as if evil will triumph over good; but this may or may not be immediately clear to the audience. In the resolution phase, the protagonist and antagonist solve their problems, either the protagonist or antagonist winning and the conflict ends. Some stories show what happens to the characters after the conflict ends and/or shows what happens to the characters much later in the future. Incidentally, this is very often seen as anti-climactic, in the sense that it could subtract from the overall message of the film or the plot structure.

\section{The Confusion of One Plot, Different Titles in Nollywood Films}

There is no gainsaying the fact that, Nollywood is fraught with various problems regarding the approaches to screenplay writing. We have examined some of these, specifically, in: "From Parts Syndrome to Seasons Syndrome in Nollywood: The Bandwagon Approach and Mercantilism in Focus" (Ayakoroma, 2017); and "Instant Miracles, Poetic Justice, 'To God be the Glory': Reflections on Developments in Nollywood" (Ayakoroma, 2016). In the main, some of the problems include, unmitigated plagiarising of foreign films; giving foreign films Nigerian settings; elongating scripts into two to four or more parts; titling film 'parts' as 'seasons', which are more or less drama episodes; and presenting a continuous storyline in two, three or four films but giving them different film titles, among several others.

As it were, the challenge in watching films having a continuous storyline in two, three or four films but are titled as different films is that, one may not know which part of the film one has and which title among such films would be the first segment of the plot. The fact is that, most times, one ends up 
watching a film in a disjointed manner, thus creating an atmosphere of confusion in the viewing experience. It thus becomes an expedition into tales of confusion as one does not follow the plot sequentially. This was exactly the case in the viewing experience of the three films selected for this study, namely, Twins but not Brothers (Anosike, 2014), Twins in Sorrow (Anosike, 2014), and Battle of the Twins (Anosike, 2014). Since there is no indication as to which film comes first, one had to look at the titles, and guessing as to which one would likely be the beginning of the story. Unfortunately, one decided to preview Battle of the Twins first, only to discover that it is the end part of the plot. Again, another decision to watch Twins but not Brothers next, thinking it would be the middle of the story was yet another error. It was discovered that, Twins in Sorrow is actually the middle part of the plot. As a point of fact, because of the way the films had been titled, without due regard to the previous title (part in the actual sense), one first watched the three films (each in two parts) in a disjointed manner. This informs the reference, in this study, to such films as, "tales of confusion.' This is because one can only get the proper sequence of such plots at the first instance if the films are watched in the proper order.

However, it is pertinent to note here that, Africa Magic on DSTV, the South African satellite broadcasting giant, in broadcasting such films, attempt to help viewers through written snippets on such films. For example, if they are broadcasting a film like Mystic Mirror (Amadi, 2014), the information after the title will include, Aka Mirror and Beauty and vice-versa. Similarly, for a film like, The Princess and the Taxi Man (Odife, 2013), it will include, a.k.a. Emenike my Love; or Emenike my Love (Odife, 2013), a.k.a. The Princess and the Taxi Man; and Royal Joy (Odife, 2013), a.k.a. Emenike my Love. For the three films selected for this study, the information would be: Twins but not Brothers, a.k.a. Twins in Sorrow; Twins in Sorrow, a.k.a. Twins but not Brothers; or Battle of the Twins, a.k.a. Twins in Sorrow. The idea is for viewers to see a film, rightly, as a sequel to the one that had been transmitted before that one or the one that is going to be broadcast subsequently, thus enhancing the film viewing experience.

\section{VOICES FROM WITHIN ON ONE PLOT, DIFFERENT TITLES...}

Some veteran Nollywood icons that were interviewed all supported the position that the proclivity to one plot, different titles and tales of confusion in Nollywood films is an aberration in the industry. For instance, Zeb Ejiro, popularly called, 'De Sheik,' has carved a niche in Nollywood because of the father figure he has created from inception. It will be recalled that Zeb Ejiro produced and directed Ripples, a popular television soap opera, which debuted on the network service of Nigerian Television Authority (NTA) in 1985; and the soap ran for five years, making history as the longest running soap (Ayakoroma, 2014, pp. 43-44). Zeb Ejiro points out thus:

Such practices are criminal and inconsistent with my training in film production. A feature film must have a beginning, a middle and an end. If a producer or director wants to produce a sequel, then he comes out with a different plot but with the same characters. This is where the Censors Board (National Film and Video Censors Board) has to live up to its mandate by not condoning such criminal and unprofessional practices. Even if you want to produce a sequel, you have to give some time to come out with a different plot. Films like Rocky starring Arnold Schwarzenegger and First Blood starring Sylvester Stallone are classic examples. This was what I did with, for example, Domitilla Pt. 2 (Oct. 1, 2015: 20.30pm).

The immediate past President of the Directors Guild of Nigeria (DGN), Andy Amenechi, is among the first set of directors that executive producers depended on in Nollywood because of his sound professional television background. He has been a prolific Nollywood director, with film credits like Rituals (1995), Ojadike (1997), Igodo (1998), Eye of the Gods (1999), Ebube (2002), and Egg of Life (2003), among others, making him more or less, the 'king of epics.' Considering his invaluable contributions to the development of Nollywood, Amenechi's view on the issue of one plot, different titles and tales of confusion in Nollywood films is instructive. He averred that,

the fault is that of the EPs, not the director. It is also a problem of the Censors Board (National Film and Video Censors Board) because they are turning a blind eye to the anomaly. An EP approaches a director with a script of about $\mathbf{1 4 0}$ scenes and you know, as a director, that that job will not be less than $2 \mathrm{hrs}(\mathbf{1 2 0} \mathrm{mins})$ running time, as opposed to a standard feature film of 90mins or 105mins max. After the film must have been edited they go back and put it in three 
or four different titles; and the Censors Board that should check such excesses does absolutely nothing. We have talked to our colleagues to insist on doing the right thing (Amenechi, Oct. 2, 2015: 20.45pm).

Chika Onu, one of the pioneer cross-over directors, has films like Living in Bondage Pt. 2 (1993), Glamour Girls (1995), and Ukwa (2001) to his credit. Currently teaching in the Department of Theatre and Film Studies, University of Port Harcourt, Port Harcourt, Rivers State, Nigeria, he had taken 'Sabbatical leave' from the industry to successfully pursue his doctorate degree. He was also unequivocal about the current tales of confusion in Nollywood, the contemporary Nigerian film industry.

It is mediocrity and greed on the part of the marketers. But then, what can we do about it? It is quite unfortunate because it is the craze in the industry, just like seasons. We know that it is unethical, and as you rightly said, we end up confusing viewers with such unprofessional, mediocre productions (Oct. 2, 2015: 2.15pm).

Clem Ohameze, veteran actor and one of the leads in the selected films also aired his views on the development thus:

It is an act of criminality that is being encouraged by the Censors Board (National Film and Video Censors Board). It is the status quo; it has become a strategy, a formula that the EPs use to make money. We are aware of the practice; but we are helpless because most of us depend on the EPs for our survival. The industry provides food on our tables; so, one cannot start a fight one cannot finish; there is also the fear that one can be sanctioned. I am happy people like you are showing serious concern on such developments. I believe as time goes on, when professionals who know what it takes to produce good films come in and work in the industry, then the industry will reinvent itself. For now, we are all forced to live with the criminality. But time will definitely sort things out (Oct. 1, 2015: 2.15pm).

University teacher and veteran Nollywood actor/director, Dr. Sam Dede (of Issakaba and Igodo fame), added his voice to the cries of despair, saying, "it is a matter of the good, the bad, and the ugly", as the marketers (EPs) brazenly do whatever they like, as far as it puts food on their table. According to him, since the EPs do the productions recklessly, with impunity, one way of checking such excesses is for professionals to take keen interest in the industry and contribute their quota towards improving ensuring global best practices. He added that, the regulatory agencies need to rise up to the occasion by sanctioning erring producers (Dede, Oct. 2, 2015: 2.15pm)..

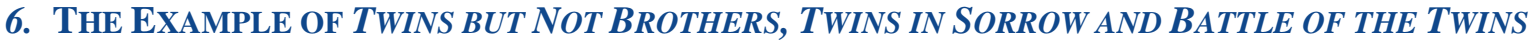

At this juncture, let us examine the plot, which runs through all the three films, Twins but not Brothers, Twins in Sorrow, and Battle of the Twins, to amplify and substantiate the point being made on the practice of "one plot, different titles and tales of confusion in Nollywood films."

\subsection{About Twins but not Brothers:}

The film, Twins but not Brothers starts with Adaugo (Patience Uzokwor) performing some incantations and walking into a smokescreen. Her request is for evil forces to frustrate one of her twins, Ikemefuna or Ikem, for short (Clems Ohameze) and make him suffer. The angst against him is that, in flagrant defiance of the religious inclination of the family, he has embraced Christianity, a strange religion at that. Also, following the demise of their father, typical of the problem associated with land ownership among the Ibos, there is dispute between Afamefuna or Afam, for short (Elvis Obi) and Ikem; and as far as their mother (Patience Uzokwor) is concerned, Afam is the head of the family, so he owns the land. Ikem confronts Afam and Mama, but she takes sides, telling him bluntly: "You seized to be my son the day you embraced that strange religion." While Ikem meets his Pastor (Pastor Chris Oguide) for counselling, Afam goes into his 'red chamber' to perform some incantations. Incidentally, the prayers from Ikem render Afam's rituals ineffective.

Not happy with the attitude of his mother in the house over the land dispute, Ikem takes the case to the Igwe (Ezenwaoilah George), who promises to summon both of them. In the face of the summons from the palace guard, Afam schemes by meeting their uncle, Mazi Obute (Ben Nwosu) to complain and giving him five thousand naira $(\mathbf{N 5 , 0 0 0 . 0 0})$ for palm wine, all in the bid to have the old man testify in 
his favour. Consequently, before the Igwe in the palace, Mazi Obute pretends that he cannot remember the real owner of the land. Since there is no valid evidence, the Igwe rules in favour of Afam. Ironically, when Ikem confronts Mazi Obute on the road later, he says: "I am beginning to remember. You should have explained to me. You know I am getting old."

In a subsequent scene, Afam sees Ikem and his family soaking garri, and goes into his bedroom to perform his incantations again. The impact is instantaneous as Afam beats his wife, Nkem over pieces of meat; and Afam pretends to be a loving brother by attempting to separate the fight. Shortly, Ikem regains consciousness and feels remorse, saying he did not know what came over him. Further diabolical acts by Afam cause the sickness of Nkem and her eventual death. In anger, Ikem's in-laws take Nkem's son, little Obinna, saying they do not want Ikem to beat him to death, as he did their daughter. As if this is not enough, Afam's next target is little Obinna, as he invokes that he should not remember his father, Ikem's people.

The Igwe, who had summoned Ikem to the palace, tells him that, he murdered Nkem. Though Ikem agrees that there was a fight and a little injury, he did not kill her; the Igwe maintains that the bottom line is that, she has died. He thus decrees that Ikem has to swear that he did not kill Nkem intentionally. Pastor (Pastor Chris Oguide) counsels Ikem against such an act, but Uncle Obute advises that he has to swear to clear his name. They eventually go to the shrine to swear, just as Afam chants from his chamber. The impact on Ikem is instant, as he is struck with madness and he starts roaming the street.

Ikem (Clem Ohameze) is seen, chained as a mad man. Pastor (Pastor Chris Oguide) gets a revelation and he goes to pray for Ikem, and he receives instant deliverance. Consequently, Ikem goes to the Igwe to ask for reprieve, arguing that his deliverance is strong evidence that he is innocent of the allegation of wilful murder of his wife. The Igwe grants him pardon, which does not go down well with Mama (Patience Uzokwor) and Afam (Elvis Obi), because she torments him at home, pouring away the little water Ikem wanted to use to wash, saying he should go to the river to fetch water for himself. Afam even restrains his little son from greeting Ikem, saying he is wicked and had killed his wife, adding that his new religion (Christianity) is a problem. Consequently, the boy refuses to fetch water for Ikem, saying he cannot do that for a man who killed his wife. Ikem's attempt to discipline the boy meets with a stern warning from his mother, who calls him, killer. The reactions of boy's mother and his twin brother, Afam, are also not palatable. On the advice of his Pastor, Ikem eventually takes a new wife, Nneoma (Jane Francis Onyebadi)).

\subsection{The Plot Continues in Twins in Sorrow:}

Years later, as the plot thickens in Twins in Sorrow, Ikem is seen, struggling to make ends meet with his wife and two children. He could not pay for his son, Prosper (Khing Bassey) to register for senior secondary certificate examinations (SSCE). His girlfriend, Juliet, gives him the seven thousand naira $(\$ 7,000.00)$ for the SSCE registration. However, since there is no money for Prosper to go to the university, his father arranges for him to go on apprenticeship in the city to learn trade. The thinking is that he will make money and continue his education from where he stopped. Somehow, Afam meets the Master's father and tries to stop the arrangement, saying Prosper is a thief; but the old man insists that Ikem is a friend and he is ready to take the risk.

Subsequently, Afam meets Ikem and his family as they are escorting Prosper, and Ikem discloses, to his wife's displeasure, that Prosper is going to the city to learn trade; and Afam pretentiously advises Prosper to be a good ambassador to the family. The next thing we see is Mama in the coven, requesting that Prosper should not succeed in the city. She is assured by the guardians of the coven that there is temptation awaiting Prosper and that he will not succeed. Prosper settles down to his apprenticeship in the city but true to the prediction of the acolytes, temptation sets in: he is seduced by his master's young wife. His refusal to accede to the woman's seduction meets with serious threat. She pretentiously reports to the husband that Prosper had attempted to rape her, making the innocent young boy to run away from the house out of fear. Left with nowhere to turn to, he starts roaming the streets, sleeping under the bridge, and doing menial jobs.

In the course of his roaming the streets in the city, Prosper meets Juliet, who had already gained admission into the university. She takes him to her apartment and gives him all the comfort she could offer, saying he will no longer do manual labour. She eventually informs him that she had talked to a 
friend to see if he could get a visa to Holland. The amount is three hundred thousand naira $(\$ 300,000.00)$ but that she has one hundred and ninety thousand naira $(\mathbf{1 9 0 , 0 0 0 . 0 0})$ and will find a way of raising the remaining amount. As promised, Juliet gets two hundred and fifty thousand naira (\$250,000.00) from her mother, saying it is for a project, and gets the visa out for Prosper. He then goes to the village to bid his parents goodbye. Again, Afam sees them seeing him off and feigns happiness at the good fortune. Mama also feigns happiness, but queries: "He did not bother to come and greet me, his grandmother?"

Meanwhile, Afam's son returns to the village and he, Afam, is not happy that the boy is returning with ordinary cellophane bag, instead of bringing money. He quarrels with the boy, who decides to leave for the city in anger. Afam retorts: "Go and make money like other children." The next thing Afam does is to go into his chamber to start his incantations: "You want your son to get rich while my son remains poor.... Prosper... Sahura! I command you to forget whoever that sent you to obodo oyinbo."

\subsection{The Plot Still Continues in Battle of the Twins}

Two years later, the plot still continues in Battle of the Twins. As if an answer to his enchantments, Silas Okonkwo (Arinze Ongwudire) returns to the village and meets Afam on the road. He tells Afam that Prosper sent the sum of twenty thousand dollars $\mathbf{( \$ 2 0 , 0 0 0 )}$ to him (Afam) to build a house for him. To Afam, this amount which translates to about three million, two hundred thousand naira (\$3.2m) is for him to change his status in the community. This is just as Prosper's girlfriend is crying over her abandoned status. Subsequently, Afam is seen driving in with his mother to their new house, as they now enjoy their new status in life. To his mother, Afam has become the richest man in town; and he has to flaunt it. Paradoxically, Ikem, the biological father of Prosper, is seen soaking garri (produced from cassava) with his family. His wife tells him that since Afam is the richest man in town, he (Ikem) should try and see him for assistance.

Expectedly, Afam refuses Ikem entering inside the house to talk; he rather talks to him standing outside. Regarding Ikem's request for financial assistance for his wife to open a shop to help in keeping the home front, Afam asks him to come back the next day. But on the way, Ikem has a spiritual attack and collapses. As a point of fact, Afam is seen performing some incantations, which apparently affect Ikem. When he is eventually taken to the hospital, he is diagnosed to have TB and blood contamination, and that a deposit of fifty thousand naira $(\mathbf{\$ 5 0 , 0 0 0 . 0 0})$ is needed to carry out an operation. His wife contacts Afam for the money but he tells her that he is going somewhere and that he will see them on his way back, a lame excuse that is blatantly affirmed by Mama. The Pastor is happy, at first, with the visit, saying it is a confirmation of his belief that, "the Lord will touch his (Afam's) heart." After many days, when Afam does not give them the money, the Pastor retorts: "This is wickedness; pure wickedness!"

Subsequently, Mazi Okute (Ben Nwosu) visits Afam, where they plan for chieftaincy titles for him (Afam) and Mama; and Afam rewards him handsomely. While his twin brother, Ikem lies critically ill, Afam and Mama are busy discussing the issue of their chieftaincy titles with Onowu (Johnlee Ukwuoma). Out of compassion, Pastor supports Ikem with ten thousand naira ( $\$ 10,000.00)$ for the hospital bill, saying God has a reason for everything, encouraging the family to keep praying and believing Him (God) for divine intervention. Unfortunately, they are able to raise only seventeen thousand naira ( $\mathbf{1 7 , 0 0 0 . 0 0}$ ) out of the sum of fifty thousand naira $(\mathbf{N 5 0 , 0 0 0 . 0 0})$ required. To prevent Ikem from dying in the hospital, the Management gives the family an ultimatum: three days within which to pay the bill or Ikem will be discharge. Sadly, Ikem's condition gets worse; so, they start a prayer session.

In another sequence, before the Igwe, Onowu makes a case for the conferment of the chieftaincy titles on Afam and Mama, arguing that they should do it before another community does it for them. In an open display of the tenets of democratic leadership, the Igwe throws the decision open to members of the Chiefs' Council. The result is $\mathbf{3}$ to $\mathbf{1}$, in favour of the conferment of the chieftaincy titles to Afam and Mama. In appreciation, for facilitating the chieftaincy conferment arrangement, Afam gives Onowu and Mazi Obute twenty thousand naira $(\mathbf{\$ 2 0 0 , 0 0 0 . 0 0})$ and fifty thousand naira $(\mathbf{\$ 5 0 , 0 0 0 . 0 0})$, respectively.

Meanwhile, Ikem's wife goes to Afam's house, in desperation; but it is to no avail. In fact, Afam tells his guard that he does not want to see her in his compound again. Thus, when she returns the next day, 
the guard tells her that, 'Oga has travelled.' She runs to Uncle Obute for a loan but he tells her that there is no money and she collapses, crying. While he encourages her, he says behind her back that, he cannot spend the money he has just got from Afam. Consequently, the chieftaincy installation of Afam and Mama takes place with a long process of adornment; and they join the Chiefs' Council, with the Igwe informing that, the actual ceremony will take place in four market days.

Pastor avers that Ikem is under bondage and that he needs deliverance. They eventually pray the Holy Ghost to take over and send down fire. Sadly, news gets to them that Ikem is dead. Ironically, Afam and his mother jeer at the death news and laugh over it; and when they later visit Ikem's widow, they shed crocodile tears. In the course of the burial arrangements, Afam agrees to buy the casket, only to send one that is nothing more than a scrap.

However, the bubble bursts as Prosper (Khing Bassey) returns suddenly and realises that his Uncle, Afam, had disappointed him. He goes to Mazi Obute, informing that he had been repatriated for nothing; and that he had been sending money to Afam instead of his father to build a house. He vows to go and meet Afam the next day to collect all the money he had sent to him. But the confrontation with Afam ends on a foul note as there are threats and counter-threats. Shaken by the development, Afam goes to his chamber and carries out some more incantations to harm Prosper. He intones: "You have bitten more than you can chew. Go mad tomorrow!" Somehow, the chants are ineffectual as Prosper prays with his Pastor. Worried by the turn of events, Afam tells Mama: "I have been humiliated. Nothing is working out." The matter is compounded as the Commissioner of Police invites him, supposedly based on a report from Prosper. In the bid to save the situation, Mama goes into her coven and tries to do some more incantations but she is struck dead instantly.

Consequent on that development, Pastor advises Prosper to leave vengeance for God; and that He will make a way for him. Prosper heeds the advice and decides to go to the city to see Juliet, who he had abandoned. Not ready to give up, Afam goes into his chamber to perform the usual rituals to kill Prosper, just as Pastor engages in a powerful prayer session. The scenes alternate because just as Afam sends "the arrow of the devil to Prosper," the Pastor commands: "Back to sender." In the course of this interchange, Afam is hit by the power of God, and in his helpless condition, he confesses all his atrocities and begs for forgiveness, before his eventual death. He confesses that he had been responsible for Ikem's death; and that he had also bewitched Prosper to have hatred for his father, Ikem, which had informed his sending money to him, Afam. He also reveals that the sworn hatred started from the day their father died; that was when Afam and their mother, Adaugo, decided to make Ikem's life miserable.

\section{Contextual Analysis of the Selected Films}

Firstly, from the plot structure, it is clear that the same story runs through all the three titles: Twins but not Brothers, Twins in Sorrow, and Battle of the Twins. In other words, it is one plot in three films. Secondly, the act of labelling the parts as individual films amounts to different titles. Thirdly, the viewing experience of the films amounts to an exercise in tales of confusion, which is prevalent in Nollywood. Apparently, this confuses viewers, as it was the case in the course of this research work. For instance, if the three films were labelled as, Battles of the Twins Pts. 1-6, one would know where to start watching the film and follow the plot as it unfolds. As a point of fact, the reason for this approach to 'one plot, different titles' borders simply on mercantilism, which does not augur well for the industry.

Another obnoxious production practice is that in the bid to elasticise or elongate the plot, between three to six scenes from the previous film or part are repeated in the next one. For instance, Pt. 1 of the first film, Twins but not Brothers, ends at the point when Ikem is seen roaming the street, as a mad man and the pastor gets a revelation about him. Pt 2 of the film still repeats about four scenes from the last part of Pt. 1, apparently to elongate the film. This pattern resonates through all the titles. Specifically, Pt. 2 of Twins but not Brothers starts at the point where Ikem is seen, married with two children, but is struggling to make ends meet, and could not pay West African Examination Council (WAEC) fee to register his son, Prosper; and the boy's girlfriend, Juliet, who is also in the school, helps him out. Somehow, these last scenes are repeated in the opening sequences in Twins in Sorrow. Furthermore, while Pt. 1 of Twins in Sorrow ends with Prosper complaining about his idleness in Juliet's place, the action of Pt. 2 repeats the last five scenes of Pt. 1, taking about 9mins 45secs of the total 58mins 23secs running time of that part. This is in addition to very long sequences of 
background music that do not contribute much to the development of the plot. When Ikem swears in the shrine and he is hit with instant madness, there is a montage, a long sequence of his mad display with a background music that runs from 50mins 20secs to 54mins 05secs of the film.

Each of the parts of the three titles runs for just between 58mins to 60mins, except Twins but not Brothers Pt. 1, which runs for 64mins 30secs. As it were, if well edited, each of the parts will not record more than 45mins running time, which translates, ideally, to a $60 \mathrm{mins}$ drama slot on television. A cursory look at the running time of each of the titles will substantiate this position.

Table 1. Duration of Films

\begin{tabular}{|l|l|l|}
\hline S/N & \multicolumn{1}{|c|}{ Film Title } & Running Time \\
\hline 1. & Twins but not Brothers Pt. 1 & 64mins. 30secs. \\
\hline 2. & Twins but not Brothers Pt. 2 & 58mins. $13 \mathrm{secs}$. \\
\hline 3. & Twins in Sorrow Pt. 1 & 59mins. $15 \mathrm{secs}$. \\
\hline 4. & Twins in Sorrow Pt. 2 & 58mins. 23secs. \\
\hline 5. & Battle of the Twins Pt. 1 & $60 \mathrm{mins}$. $30 \mathrm{secs}$. \\
\hline 6. & Battle of the Twins Pt. 2 & 60mins. 25secs. \\
\hline
\end{tabular}

Source: Personal Preview

Of interest also is that, the same end credits run through all the three titles. This is irrespective of the fact that some of the characters do not feature in some of the parts. It is thus not surprising that typographic mistakes in the opening or end credits are not corrected in all the three films. For example, there are graphics like "Execuive Producer," "Jane Francies Onyebadi," and "Twince but not Brothers."

\section{CONCLUSiON}

From the plot structure of the film examined above, it is clear that the same storyline runs through all the three titles. The act of labelling them differently amounts to confusing viewers, just as it was experienced in the course of this work. They should have just been labelled as parts. If they were labelled as Battles of the Twins Pts. 1-6, for instance, one would know where to start watching the film and follow the plot as it unfolds. It could be argued that the reason for this approach to 'one plot, different titles' borders simply on mercantilism and is not in the best interest of the industry. For instance, there are repeats of between three to six scenes from the previous film or part. This is all in the bid to elasticise or elongate the film. Also, the same end credits run through all the three titles. Unfortunately, typographic errors in the credits are not corrected in all the three films. Some of the most glaring ones are: "Execuive Producer," "Franceis," and "Twince," among others. Furthermore, each of the parts run for just between 58mins to 60mins, which, if well edited will not be more than 45mins running time, which ideally translates to a $60 \mathrm{mins}$ TV programme slot. They could be more or less drama episodes.

In conclusion, it could be posited that, Bobemmanuel Anosike's Twins but not Brothers, Twins in Sorrow, and Battle of the Twins, are films with a common plot, substantiating our postulation of 'one plot in different titles and tales of confusion in Nollywood films.' Even if films are to be packaged as sequels, production conventions need to be followed to enhance the content of such films. As stated earlier, the proclivity to the presentation of a continuous storyline in two, three or four films, which are given different film titles, entails elongating the scripts unnecessary, thus making them to be porous. This practice is reflective of the 'trader mentality' of unscrupulous executive producers in Nollywood, which needs to be checked by the regulatory bodies. The challenge, therefore, is for the National Film and Video Censors Board (NFVCB) to bring sanity to the unethical practice.

\section{REFERENCES}

[1] Amenechi, A. Telephone interview at 20.45pm, on Oct. 1, 2015.

[2] Ayakoroma, B. F. From Parts Syndrome to Seasons Syndrome in Nollywood: The Bandwagon Approach and Mercantilism in Focus. In Iji, E., Betiang, L., \& Andrew-Essien, E. (Eds.), Theatre and media in the new millennium. Ibadan: Kraft Books, 2017: 34-47.

[3] Ayakoroma, B. F. Instant Miracles, Poetic Justice, 'To God be the Glory': Reflections on Developments in Nollywood. In Okome, O. \& Okhakhu, M. (Eds.), Media studies in Nigeria: Genesis and detours. Ibadan: Stirling-Horden, 2016: 89-108. 
One Plot, Different Titles and Tales of Confusion in Nollywood Films: The Example of Bobemmanuel Anosike's Twins but not Brothers, Twins in Sorrow, and Battle of the Twins

[4] Ayakoroma, B. F. Theatre management in Nigeria: An introduction. Ibadan: Kraft Books, 2013.

[5] Ayakoroma, B. F. Trends in Nollywood: A study of selected genres. Ibadan: Kraft Books, 2014.

[6] Bordwell, D., \& Thompson, K. Film art: An introduction (Int'l ed.). New York: McGraw-Hill, 1993.

[7] Dede, S. Telephone interview at 3.00pm on Oct. 2, 2015.

[8] Dukore, B. Dramatic theory and criticisms: Greeks to Grotowski. New York: Holt, Rinehart \& Winston, 1989.

[9] Ekwuazi, H. Film in Nigeria. Jos: Nigerian Film Corporation, 1987.

[10] Ginnatti, L. Understanding movies ( $9^{\text {th }}$ ed.). New Jersey: Prentice-Hall, 2002.

[11] Harmon, R. Film producing: Low-budget films that sell. Hollywood: Samuel French Trade, 1988.

[12] Mamer, B. Film production techniques: Creating the accomplished image (4 ${ }^{\text {th }}$ ed.). Belmont, CA: Thomson \& Wadsworth, 2006.

[13] Monaco, J. How to read a film: The world of movies, media, and multimedia ( $3^{\text {rd }}$ ed.). New York \& Oxford: Oxford University Press, 2000.

[14] Ohameze, C. Telephone interview at 21.45pm, on Oct. 1, 2015.

[15] Onu, C. Telephone interview at 2.15pm, on Oct. 2, 2015.

[16] "Plot". Accessed 1 Oct. 2015 from https://en.wikipedia.org/wiki/Plot_(narrative)\# Usage

[17] Rabiger, M. Directing: Film techniques and aesthetics ( $3^{\text {rd }}$ ed.). London \& Boston: Focal Press, 2003.

[18] Stam, R. Film theory: An introduction. Massachusetts \& Oxford: Blackwell Pubs, 2000.

[19] Straczynski, J. M. The complete book of scriptwriting (Rev. ed.). Cincinnati, Ohio: Writer's Digest Books, 1996.

[20] The new Webster's dictionary of the English language, Int. ed. New York: Lexicon, 1995.

\section{SELECT FILMOGRAPHY}

[21] Anosike, Bobemmanuel (Director). Battles of the twins. Story: Gabriel Awaji. DoP: Kelin Black Aburimen. Producer: Gabriel Awaji. Perf.: Clem Ohameze, Patience Uzokwor, Elvis Obi, Ben Nwosu, Doris Ogala, Khing Bassey, Pastor Chris Oguike, Jane Francies Onyebadi, Lillian Okorie. Company: Wedtjet Movies Production Ltd, 2014.

[22] Anosike, Bobemmanuel (Director). Twins but not brothers. Story: Gabriel Awaji. DoP: Kelin Black Aburimen. Producer: Gabriel Awaji. Perf.: Clem Ohameze, Patience Uzokwor, Elvis Obi, Ben Nwosu, Doris Ogala, Khing Bassey, Pastor Chris Oguike, Jane Francies Onyebadi, Lillian Okorie. Company: Wedtjet Movies Production Ltd, 2014.

[23] Anosike, Bobemmanuel (Director). Twins in sorrow. Story: Gabriel Awaji. DoP: Kelin Black Aburimen. Producer: Gabriel Awaji. Perf.: Clem Ohameze, Patience Uzokwor, Elvis Obi, Ben Nwosu, Doris Ogala, Khing Bassey, Pastor Chris Oguike, Jane Francies Onyebadi, Lillian Okorie. Company: Wedtjet Movies Production Ltd, 2014.

\section{AUTHOR's BIOGRAPHY}

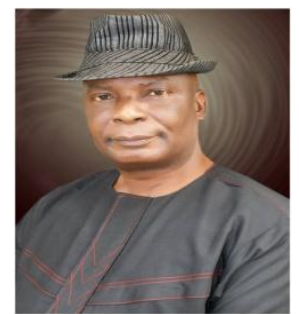

Dr. Barclays Foubiri AYAKOROMA(BFA), former Executive Secretary/CEO of National Institute for Cultural Orientation (NICO), Abuja-FCT, read Theatre Arts at the Universities of Calabar, Ibadan, and Port Harcourt, all in Nigeria, specialising in Film Studies. With several journal articles, edited books and plays, including A Matter of Honour and Dance on his Grave, to his credit, BFA is the author of the ground-breaking Trends in Nollywood: A Study of Selected Genres, as well as Theatre Management in Nigeria: An Introduction.He is the current Editor of Nigerian Theatre Journal: A Journal of the Society of Nigeria Theatre Artists (SONTA), a Fellow of SONTA,a Member of Nollywood's Directors Guild of Nigeria and Associate Professor at Nasarawa State University, Keffi (NSUK), Nigeria.

Citation: Barclays Foubiri AYAKOROMA. "One Plot, Different Titles and Tales of Confusion in Nollywood Films: The Example of Bobemmanuel Anosike's Twins but not Brothers, Twins in Sorrow, and Battle of the Twins". International Journal of Humanities Social Sciences and Education (IJHSSE), vol 5, no. 7, 2018, pp. 127-136. doi: http://dx.doi.org/10.20431/2349-0381.0507014.

Copyright: () 2018 Authors. This is an open-access article distributed under the terms of the Creative Commons Attribution License, which permits unrestricted use, distribution, and reproduction in any medium, provided the original author and source are credited. 